CLASSICAL AND NONCLASSICAL LOGICS 



\section{CLASSICAL AND NONCLASSICAL LOGICS}

An Introduction to the Mathematics of Propositions

Eric Schechter

Princeton University Press

Princeton and Oxford 
Copyright (c) 2005 by Princeton University Press

Published by Princeton University Press, 41 William Street, Princeton, New Jersey 08540

In the United Kingdom: Princeton University Press, 3 Market Place, Woodstock, Oxfordshire OX20 1SY

All Rights Reserved

\section{Library of Congress Cataloging-in-Publication Data}

Schechter, Eric, 1950

Classical and nonclassical logics : an introduction to the mathematics of propositions / Eric Schechter.

p. $\mathrm{cm}$.

Includes bibliographical references and index.

ISBN-13: 978-0-691-12279-3 (acid-free paper)

ISBN-10: 0-691-12279-2 (acid-free paper)

1. Mathematics-Philosophy. 2. Proposition (Logic). I. Title.

QA9.3.S39 2005

$160-\mathrm{dc} 22 \quad 2004066030$

British Library Cataloging-in-Publication Data is available

The publisher would like to acknowledge the author of this volume for providing the camera-ready copy from which this book was printed.

Printed on acid-free paper. $\infty$

pup.princeton.edu

Printed in the United States of America

10987654321 